\title{
- PORÓD W WARUNKACH DOMOWYCH - OPIEKA POŁOŻNEJ PODCZAS PORODU I W POŁOGU
}

\author{
HOME BIRTH - MIDWIVES' CARE DURING CHILDBIRTH AND POSTPARTUM \\ Sara Suchowiak ${ }^{1, \text { a }}$, Małgorzata Kłobus², Katarzyna Plagens-Rotman², b \\ ${ }^{1}$ Uniwersytet Medyczny im. Karola Marcinkowskiego w Poznaniu \\ ${ }^{2}$ Katedra Zdrowia Matki i Dziecka, Uniwersytet Medyczny im. Karola Marcinkowskiego w Poznaniu \\ ${ }^{a}$ https://orcid.org/0000-0002-0688-384X \\ ${ }^{\mathrm{b}} \mathrm{https}: / /$ orcid.org/0000-0001-7646-7430
}

DOI: https://doi.org/10.20883/pielpol.2020.8

\begin{abstract}
STRESZCZENIE
Porody domowe w Polsce wciąż zajmują jedynie niewielki odsetek wszystkich porodów, jednak coraz więcej kobiet myśli o rozwiązaniu ciąży w warunkach pozaszpitalnych. Motywacje kobiet są różnorodne, wśród najważniejszych można wyróżnić: ograniczenie do minimum interwencji medycznych i niezakłócenie naturalnego przebiegu porodu oraz dom jako miejsce narodzin, które gwarantuje bezpieczeństwo i optymalne warunki do porodu.

Aby przystąpić do porodu w warunkach domowych ciężarna musi przejść odpowiednią kwalifikację medyczną. W procesie przygotowań do takiego porodu bierze się pod uwagę przeszłość położniczą, stan zdrowia ciężarnej i dobrostan dziecka. Jest to możliwość, dla rodziców, którzy są silnie przekonani do takiego sposobu rozwiązania ciąży oraz są gotowi wziąć na siebie odpowiedzialność związaną z tym wyborem.

Większość badań naukowych z różnych krajów nie wykazuje korelacji pomiędzy środowiskiem narodzin a wzrostem ryzyka śmierci okołoporodowej dla matki i dziecka. Bezpieczeństwo zapewniają: prawidłowa kwalifikacja do porodu, obecność doświadczonej położnej oraz odpowiednio zorganizowany transfer do szpitala.

Podczas porodu położne opierają się na Modelu opieki nad kobietą i dzieckiem w fizjologicznym okresie okołoporodowym w praktyce pozaszpitalnej. Wytyczne te są zgodne z obowiązującymi standardami medycznymi.
\end{abstract}

SŁOWA KLUCZOWE: położnica, noworodek, opieka, poród domowy.

\section{Wstęp}

W Polsce zgodnie z Rozporządzeniem Ministra Zdrowia z dnia 23 września 2010 r. w sprawie standardów postępowania oraz procedur medycznych przy udzielaniu świadczeń zdrowotnych z zakresu opieki okołoporodowej sprawowanej nad kobietą w okresie fizjologicznej ciąży, fizjologicznego porodu, połogu oraz opieki nad noworodkiem, istnieje możliwość porodów pozaszpitalnych. Dodatkowo każda położna posiadająca prawo

\begin{abstract}
In Poland home births still account for only a small proportion of all births. However, an increasing number of women are considering giving birth in a non-clinical setting. Their motives are diverse; among the most common there can be distinguished: limiting medical interventions to the minimum and not interrupting the natural labour and delivery process, and treating home as a safe place with optimal surroundings for childbirth.

Before attempting home birth, the expectant mother must be thoroughly examined and qualified as healthy. While preparing for such labour the factors taken into consideration are the mother's past obstetric history, her current health condition and the welfare of the child. Home birth is an alternative for those parents who are entirely confident of such an approach to labour and delivery, and ready to take full responsibility for their decision.

The majority of scientific studies from different countries do not demonstrate any correlation between birthing environments and a greater risk of perinatal death to neither the mother nor the child. Their safety is ensured by correct medical qualification, the presence of an experienced midwife and appropriate arrangements for transfer to hospital.

Midwives attending births use (the Midwifery Model of Care for Childbearing Women and their Children during the Physiological Perinatal Period in Non-clinical Practice). These guidelines are compliant with the applicable medical standards.
\end{abstract}

KEYWORDS: women in childbirth, newborn, care, home birth.

wykonywania zawodu, zgodnie z ustawą z dnia 5 lipca 1996 r. o zawodach pielęgniarki i położnej, w swoich kompetencjach zawodowych posiada uprawnienia do prowadzenia i przyjęcia porodu fizjologicznego, niezależnie od warunków, w jakich się on odbywa [1-2].

Współczesne położnictwo, oprócz rozwoju w dziedzinie bezpieczeństwa okołoporodowego kobiet, musi także wyjść naprzeciw oczekiwaniom dotyczących porodu naturalnego. Z powodu zwiększającej się świado- 
mości społeczeństwa oraz powrotu do życia w zgodzie z naturą, wiele osób ma nadzieję na poród aktywny i naturalny, bez ingerencji w fizjologiczny przebieg narodzin.

Szpitale starają się dostosować swoje sale porodowe i procedury postępowania do oczekiwań kobiet, jednak nie wszędzie są one respektowane i dla części ciężarnych nie jest to rozwiązanie satysfakcjonujące. Alternatywą stają się porody w warunkach domowych.

\section{Poród w warunkach domowych}

W obecnych czasach środowiska medyczne i szpitale wychodzą naprzeciw oczekiwaniom porodowym kobiet oraz stosują nowe uregulowania prawne stworzone w celu poprawy warunków porodu. Jednak nie wszędzie standardy te są respektowane, a dla niektórych rodziców proponowane rozwiązania są niewystarczające. Alternatywą stają się porody domowe, jednak nie każda ciężarna może skorzystać z takiej możliwości. Porody pozaszpitalne są przewidziane dla osób, które czują się przekonane do takiego sposobu rozwiązania ciąży i są gotowe wziąć na siebie odpowiedzialność związaną z tym wyborem. W kwalifikacji medycznej do porodu domowego bierze się pod uwage przede wszystkim fizjologiczny przebieg ciąży [3-4].

Motywy kobiet wybierających poród w domu są różnorodne. Pewna grupa rodziców, która doświadczyła porodów w szpitalu uważa, że nie jest to miejsce ukierunkowane na „przyjmowanie życia”, lecz na „ratowanie życia”. Zgodnie z tą zasadą poświęca się komfort zarówno fizyczny, jak i psychiczny rodziców i rodzącego dziecka. Do norm i przepisów obowiązujących w szpitalu muszą dostosować się nie tylko pacjenci, ale również personel medyczny. Paradoksalnie pomimo wykwalifikowanej kadry medycznej i profesjonalnego sprzętu dla niektórych rodzących poród w szpitalu nie jest równoznaczny z porodem bezpiecznym. Poczucie bezpieczeństwa zapewnia im środowisko domowe, które znają i czują się w nim swobodnie [5].

Argumenty osób wybierających dom jako miejsce narodzin to:

- $\quad$ rodząca i jej dziecko stają się najważniejsi i cała uwaga położnej skierowana jest na nich, nie ma innych pacjentów i obowiązków [5-7];

- $\quad$ kobieta nie zostaje wyrwana ze swojej codzienności, nie zamienia się w pacjentkę zależną od obowiązujących w szpitalu zasad; to ona kontroluje sytuację i decyduje o tym, co pragnie robić w danej chwili $[6,8]$;

- $\quad$ podczas porodu kobieta ma całkowitą swobode ruchu oraz sama instynktownie wybiera wygodne dla niej pozycje porodowe [5, 7, 9];

- $\quad$ podczas II okresu porodu rodząca może zdecydować, gdzie i w jakiej pozycji chciałaby urodzić dziecko, np. w wannie [5, 8-10];
- $\quad$ noworodek przychodzi na świat w miejscu i warunkach, które wybrała oraz przygotowała dla niego matka, bez zbędnego oświetlenia, głosów i dotyków [6, 9];

- $\quad$ w środowisku domowym występuje bezpieczniejsza flora bakteryjna dla matki i dziecka niż drobnoustroje, które znajdują się w szpitalu [6];

- rodząca przeżywa intymny moment porodu z osobami, które sama wybrała i obdarzyła zaufaniem [6, 9];

- $\quad$ w porodzie domowym interwencje medyczne ogranicza się do minimum [6, 10];

- $\quad$ poród staje się wydarzeniem wpisanym w codzienność całej rodziny: starsze dzieci nie odczuwają nieobecności matki, nie mają wrażenia, że nowy członek rodziny „odebrał” im rodziców; akceptacja młodszego rodzeństwa i adaptacja do nowej sytuacji staje się dla dzieci łatwiejsza oraz płynniejsza [5, 7, 10];

- atmosfera spokoju pozwala niekiedy rodzącej na odczuwanie podczas porodu wrażeń metafizycznych [5, 7, 10];

- $\quad$ ojciec dziecka jest u siebie w domu, przez co nie krępuje się i wie, co może robić oraz w jaki sposób pomóc rodzącej, dodatkowo ułatwia to parze swobodne okazywanie sobie nawzajem uczuć [5-7];

- poród domowy może dać kobiecie poczucie siły, przekonać ją o własnej samodzielności dzięki temu, że sama urodziła dziecko bez ingerencji personelu i interwencji medycznych [6-8].

Zawód położnej w Polsce daje uprawnienia do samodzielnego przyjmowania i prowadzenia porodu fizjologicznego zarówno w warunkach szpitalnych, jak i pozaszpitalnych z zachowaniem standardów postępowania medycznego [1]. Zgodnie z Rozporządzeniem Ministra Zdrowia ciężarna może wybrać miejsce porodu w warunkach szpitalnych lub pozaszpitalnych, w których czuje się bezpiecznie, oraz ma prawo wybrać osobę, która poprowadzi jej ciążę i przyjmie poród [2].

Narodowy Fundusz Zdrowia opracowuje zasady dotyczące refundacji takich narodzin, będzie to dodatkowym dokumentem regulującym i potwierdzającym zasadność praktykowania porodów domowych [12].

W Polsce porody domowe wciąż zajmują jedynie niewielki odsetek wszystkich porodów. W raporcie Głównego Urzędu Statystycznego w latach 1980-2014 można zaobserwować ogólną tendencję spadkową wszystkich porodów, konsekwentnie także porodów pozaszpitalnych z pomocą specjalisty - można z tego wywnioskować, że do tej grupy należą również porody domowe z udziałem położnej. W 1980 r. zarejestrowano ogółem 701659 porodów, w tym 27434 w izbie porodowej i $4806 \mathrm{w}$ innym miejscu z profesjonalistą 
(w tym w domu). Porody szpitale stanowiły wtenczas niecałe 95\% wszystkich porodów. Natomiast w 2014 r. odbyło się 377003 porodów, w tym 335 w środowisku pozaszpitalnym, odsetek porodów szpitalnych wynosił około 99,8\% [13-14].

W Polsce działa stowarzyszenie Niezależna Inicjatywa Rodziców i Położnych Dobrze Urodzeni. Zrzesza ona między innymi położne przyjmujące porody domowe i rodziców zainteresowanych tym tematem. Celem działania organizacji jest przede wszystkim rozpowszechnianie, propagowanie i umożliwianie porodu naturalnego niezależnie od warunków, w których się on odbywa. Położne z tej organizacji przyjmują około połowę wszystkich porodów w warunkach domowych. Stowarzyszenie prowadzi własną dokumentację medyczną i statystyki. Według danych z lat 2010-2015 1118 kobiet wyraziło chęć rodzenia w środowisku domowym. Ostatecznie odbyło się 630 porodów domowych, z czego 105 zakończyło się transferem, pozostałe 383 kobiety urodziły we własnym mieszkaniu. Największą liczbę przyjętych porodów odnotowano w 2015 r., najmniejszą w 2013 r. Na przestrzeni sześciu lat można zaobserwować tendencję wzrostową urodzeń w domu w asyście położnej z fundacji. Analizując ilość porodów w poszczególnych województwach, stwierdza się, iż największa ilość odbyła się w województwie mazowieckim, a następnie wielkopolskim. Według danych stowarzyszenia zdecydowana większość matek decydujących się na poród w warunkach domowych ma wykształcenie wyższe i ponad połowa z nich to wieloródki [15].

Według danych z The European Perinatal Health Report 2010 najwięcej porodów domowych odbywa się w Holandii, następnie w Stanach Zjednoczonych i Islandii [16].

Przy dopuszczeniu do porodu domowego dużą rolę ma doświadczenie osoby dokonującej kwalifikacji. W procesie tym bierze udział nie tylko położna, ale także lekarz ginekolog. Położna spotyka się kilka razy w trakcie ciąży z kobietą, która zgłosiła swoją chęć do porodu domowego, w celu wzajemnego poznania się i nabrania zaufania. Spotkania te umożliwiają położnej kontrolowanie stanu fizycznego i psychicznego ciężarnej. Kobieta musi wykonać wszystkie badania zalecane przez Polskie Towarzystwo Ginekologiczne. Na podstawie zebranych informacji określa się, czy istnieją przeciwwskazania do porodu w warunkach domowych oraz czy istnieje szansa, by pomimo wykrycia niektórych z nich możliwe było rozważenie takiego rodzaju ukończenia ciąży [17].

Przeciwwskazania do porodu pozaszpitalnego, według polskiego modelu dotyczącego postępowania w trakcie porodów pozaszpitalnych opracowanego przez stowarzyszenie Dobrze Urodzeni, dzieli się na bezwzględne i względne. Występowanie czynników z pierwszej grupy przeciwwskazań dyskwalifikuje kobietę do porodu poza szpitalem. W przypadku drugiej grupy przeciwwskazań (względnych) warunkiem do odbycia porodu domowego jest ich ścisła weryfikacja i kontrola. Ostateczną decyzję podejmuje się na podstawie opinii specjalistów (położnej, lekarza) oraz przyszłych rodziców [18].

\section{Bezpieczeństwo porodów w warunkach domowych}

Sprawa bezpieczeństwa porodów domowych wciąż budzi wiele kontrowersji. Na całym świecie przeprowadza się analizy danych porównujące bezpieczeństwo porodu w zależności od miejsca, w którym się on odbywa. $\mathrm{Na}$ podstawie wyników badań i własnych przekonań międzynarodowe towarzystwa i organizacje medyczne wydają swoje opinie na temat bezpieczeństwa narodzin pozaszpitalnych.

The American College of Obstetricians and Gynecologists (ACOG) wydało oświadczenie, według którego szpital i akredytowane centra porodowe są najbezpieczniejszym środowiskiem do porodu, jednak każda kobieta ma prawo do własnej decyzji opartej na wiedzy medycznej. Ciężarna, która planuje poród w środowisku domowym, powinna być poinformowana o ryzyku i korzyściach wypływających z takiego rodzaju ukończenia ciąży na podstawie najnowszych badań naukowych. Podczas rozmowy z ciężarną personel medyczny powinien zaznaczyć, że poród w domu związany jest ze zmniejszeniem interwencji medycznych w porównaniu z porodem w szpitalu, jednakże podwójnie wzrasta ryzyko śmierci płodu i potrójnie ryzyko drgawek i poważnych dysfunkcji neurologicznych u noworodka [20].

National Institute for Health and Care Excellence (NICE) w swoich rekomendacjach orzeka, że poród w domu jest ogólnie bardzo bezpieczny zarówno dla pierworódki, jak i wieloródki z ciążą niskiego ryzyka oraz ich dzieci. Personel medyczny powinien informować o tym ciężarne oraz oznajmić, że poród w warunkach domowych jest dla nich korzystny ze względu na niższą ilość interwencji medycznych oraz porównywalne ryzyko wystąpienia powikłań u dziecka. Dodatkowo w domu zwiększa się szansa na spontaniczny, naturalny poród siłami natury (zmniejsza się ryzyko episiotomii, zabiegowego ukończenia porodu, cięcia cesarskiego) [21].

Bezpieczeństwo porodów w warunkach domowych zapewniają trzy elementy:

- prawidłowa kwalifikacja do porodu,

- $\quad$ obecność położnej, która dzięki swojej wiedzy i doświadczeniu potrafi wcześnie zauważyć, że poród zaczyna odbiegać od fizjologii, 
- odpowiednio zorganizowany sposób transferu do szpitala [20, 23-24].

Dobrze zorganizowany transport jest nieoceniony w sytuacji zagrożenia życia matki i/lub dziecka w trakcie porodu w warunkach domowych. Wskazane jest, by każda położna deklarująca przyjmowanie porodu w warunkach domowych zawarła umowę transferową przynajmniej z jednym szpitalem. W przypadku wystąpienia wskazań do przewozu pacjentki do szpitala położna prowadząca wzywa karetkę Stacji Pogotowia lub Stacji Transportu Sanitarnego, w zależności od zawartej umowy. Dopuszczalne jest przewiezienie pacjentki samochodem prywatnym, jednakże w tym wypadku nie powinna prowadzić położna, która w tym czasie pozostaje z rodzącą aż do momentu przekazania jej pod opiekę zespołu medycznego [18-19].

Publikacje analizujące transfer do szpitala podczas porodu w warunkach domowych pokazują, że taka sytuacja ma miejsce w przypadku 9,9\% do 31,9\% porodów, w zależności od badań. Znacznie wyższe wskaźniki dotyczą pierworódek (od 23,4\% do 45,5\%) niż wieloródek (5,8\% do 12,0\%). Transfery mają częściej miejsce, gdy porody domowe są integralną częścią sytemu medycznego, niż gdy indywidualnie praktykują je niezależne położne. Najczęstsze opisywane przyczyny to zbyt wolny postęp porodu (w przypadku 5,2\%, do 9,8\% porodów) oraz dystocja barkowa (od 5,1\% do 9,8\% porodów) [25].

W Polsce dane na temat transferów okołoporodowych gromadzi i udostępnia stowarzyszenie Dobrze Urodzeni. W latach 2010-2015 odbyło się 630 porodów domowych, z czego 105 zakończyło się transferem (16,7\%). Zdecydowanie najczęstszym momentem przewiezienia kobiety do szpitala był I okres porodu. W tym etapie porodu do przyczyn przewozu można zaliczyć: brak postępu porodu, odpływanie zielonego płynu owodniowego, brak postępu porodu przy PROM, nieprawidłowe ułożenie główki oraz nieprawidłowy FHR. Wśród innych istotnych czynników determinujących decyzję o transferze do szpitala można wymienić: patologię III okresu porodu oraz potrzebę farmakologicznego zmniejszenia bólu porodowego. Wśród noworodków urodzonych w środowisku domowym, 12 z nich wymagało hospitalizacji, w tym 8 w pierwszej dobie po porodzie. Powodem przewiezienia dziecka do szpitala były między innymi: niska punktacja wg skali V. Apgar, nieprawidłowe wyniki badań po porodzie oraz wrodzone zapalenie płuc [15].

Jedne z największych badań, jakie do tej pory opublikowano, dotyczące bezpieczeństwa porodów domowych, wykonano w Holandii. Celem było porównanie śmiertelności i zachorowalności okołoporodowej kobiet z ciążą niskiego ryzyka podczas porodu domowego i szpitalnego. Przeanalizowano 529688 porodów, z czego 321307 (60,7\%) odbyło się planowo w warunkach domowych, a 163261 (30,8\%) miało miejsce planowo w szpitalu, dla reszty $45120(8,5 \%)$ miejsce porodu było nieznane [23].

W badaniu rozpatrzono śmiertelność okołoporodową kobiet, śmierć noworodków śródporodową, do 24 godzin po porodzie i do siedmiu dni po porodzie oraz przyjęcie noworodka na oddział intensywnej opieki. W analizie nie wykazano istotnej różnicy w śmiertelności okołoporodowej pomiędzy porodem szpitalnym a porodem domowym. Miejsce porodu nie miało wpływu na wskaźniki śmiertelności okołoporodowej [23].

W 2014 r. opublikowano rozszerzenie badania. Autorzy przeanalizowali 743070 holenderskich porodów niskiego ryzyka, z czego 466112 miało miejsce w domu, a 276958 w szpitalu. Badano śródporodową śmiertelność kobiet i noworodków, ilość punktów w skali Apgar i przyjęcie na oddział intensywnej terapii noworodka w okresie do 28 dni po porodzie. W badaniu nie wykazano zwiększonego ryzyka szkodliwych następstw porodowych wśród kobiet niskiego ryzyka rodzących w domu. Wyniki odnoszą się tylko do regionów, gdzie porody domowe są dobrze zintegrowane z położniczym systemem opieki [26].

Badanie przeprowadzone w Ontario, opublikowane w 2016 r. obejmowało 11493 planowych porodów domowych i tyle samo planowanych porodów szpitalnych. Nie wykazano zwiększonego ryzyka dla matki i dziecka podczas porodów domowych zarówno dla pierworódek, jak i wieloródek (z niskim ryzykiem wystąpienia powikłań okołoporodowych). Z badania wynika, że episiotomia wykonywana była rzadziej w domu, aczkolwiek zabieg nacięcia krocza stosowano rzadko także w szpitalu. Niskie wskaźniki wykonania episiotomii nie korelowały ze zwiększonym odsetkiem uszkodzeń krocza. Krwawienia poporodowe dotyczyły 2,5\% kobiet rodzących w domu i 3,0\% rodzących w szpitalu. Transfer do szpitala był konieczny w 8,8\% wszystkich porodów domowych.

Odsetek resuscytacji noworodka, śmierci okołoporodowej, 4 lub mniej punktów w skali Apgar w 5. minucie życia były porównywalne niezależnie od środowiska porodu [27].

Według statystyk stowarzyszenia Dobrze Urodzeni w Polsce w ostatnich sześciu latach większość kobiet urodziła dziecko bez żadnych urazów krocza, a nacięcie krocza wykonano tylko w pojedynczych przypadkach. U części kobiet doszło do spontanicznych uszkodzeń (pęknięcie I i Il stopnia) wymagających niewielkiego zaopatrzenia chirurgicznego. Episiotomię wykonano tylko przy dwudziestu siedmiu porodach. Nie odnotowano uszkodzeń krocza III lub IV stopnia [15].

Istnieją również badania wykazujące niewielki wzrost ryzyka śmierci, drgawek noworodkowych oraz innych patologii, jednak przeważająca większość ba- 
dań z różnych krajów nie wykazuje korelacji pomiędzy środowiskiem narodzin a wzrostem ryzyka śmierci okołoporodowej dla matki i dziecka. Odsetek interwencji medycznych i komplikacji okołoporodowych (krwotoki poporodowe, pęknięcia krocza) w porównaniu planowanych porodów domowych ze szpitalnymi jest mniejszy w środowisku domowym, zwiększa się tu także satysfakcja z doświadczonego porodu [28-30].

\section{Rola położnej podczas porodu w warunkach domowych}

Zespół położnych zrzeszonych w stowarzyszeniu Niezależna Inicjatywa Rodziców i Położnych Dobrze Urodzeni opracował Model opieki nad kobietą i dzieckiem w fizjologicznym okresie okołoporodowym w praktyce pozaszpitalnej [18]. Wytyczne są zgodne z obowiązującymi standardami medycznymi. Dotyczą one kobiet z prawidłowym przebiegiem ciąży, które pragną rodzić w warunkach domowych. Zalecenia te zostały stworzone m.in. dla położnych w celu określenia i ujednolicenia standardów postępowania przy kwalifikacji pacjentki do porodu, działań podejmowanych podczas fizjologicznie lub patologicznie przebiegającej akcji porodowej w domu.

\section{Przygotowanie położnej do przyjęcia porodu domowego}

Położna, która przyjmuje porody domowe powinna nawiązać współpracę między innymi z lekarzem ginekologiem, pediatrą, szpitalem, laboratorium, kolumną transportu sanitarnego. Stwarza to bezpieczne warunki okołoporodowe i poporodowe dla kobiety i jej dziecka. Współdziałanie z lekarzem położnikiem-ginekologiem polega na konsultacji przynajmniej trzy razy w trakcie trwania ciąży (w I, II i III trymestrze) i raz w połogu (w 6. tygodniu po porodzie) oraz każdorazowo w przypadku wystąpienia komplikacji. Współpraca z lekarzem pediatrą polega na umówieniu wizyty domowej w 1. dobie życia dziecka oraz konsultacji w przypadku stwierdzenia nieprawidłowości podczas wizyt patronażowych. Umowa ze szpitalem umożliwia konsultacje ciążowe, które obejmują ultrasonografię i kardiotokografię oraz transfer śródporodowy lub poporodowy. Współpraca z laboratorium daje możliwość diagnostyki i uzyskania wyników, również telefonicznie, pobranego materiału biologicznego w trakcie lub po porodzie [18-19].

Do przygotowania położnej można zaliczyć również prawidłową kwalifikację ciężarnej do porodu pozaszpitalnego na podstawie wykonywanych badań i wywiadu medycznego. Prócz tego niezwykle ważne jest prawidłowe ustalenie terminu porodu. Ocena wieku ciążowego, a co za tym idzie wyliczenie przewidywanego terminu porodu, pozwala zarówno ciężarnej, jak i położnej zaplanować czas w okolicy spodziewanego dnia porodu. Dodatkowo jest to istotna informacja pozwalająca rozpoznać ewentualną hipotrofię płodu czy poród przedwczesny [18, 31-32].

Położna, przygotowując się do porodu domowego, musi posiadać niezbędne narzędzia umożliwiające jej bezpieczne przyjęcie porodu fizjologicznego, a także aktywne postępowanie przy stanie zagrożenia życia w okresie oczekiwania na transport medyczny.

Według modelu w praktyce pozaszpitalnej położne niezależne działają w zespole położnych ściśle ze sobą współpracującym. Ciężarna, która zamierza rodzić w domu oraz jej rodzina znajdują się pod opieką całego zespołu, jednak główny nadzór sprawuje położna prowadząca, która w asyście innej położnej z zespołu przyjmuje poród pozaszpitalny, a następnie sprawuje kontrolę nad kobietą w połogu [18].

Wskazane jest, aby w porodzie domowym uczestniczyły dwie osoby z wykształceniem medycznym. Powinny one mieć kurs z przeprowadzania resuscytacji krążeniowo-oddechowej, dodatkowo co najmniej jedna osoba powinna mieć praktyczne doświadczenie w przeprowadzaniu tych czynności [24, 33].

\section{Rola położnej podczas porodu}

Poród rozpoznajemy w chwili wystąpienia regularnej czynności skurczowej macicy (przynajmniej co $10 \mathrm{mi}-$ nut), która powoduje skracanie i rozwieranie się szyjki macicy, aż do pełnego rozwarcia. Położna przyjeżdżająca do domu rodzącej w okresie rozwierania ocenia jej stan zarówno fizyczny, jak i emocjonalny, dobrostan płodu oraz postęp porodu. Następnie na podstawie zebranych wyników podejmuje decyzję o kontynuacji porodu w warunkach domowych lub potrzebie transferu do szpitala.

Kontynuacja opieki położniczej nad rodzącą w domu opiera się na:

- nawiązaniu i utrzymaniu kontaktu z rodzącą i osobą bliską, co zapewnia poczucie bezpieczeństwa i godności osobistej,

- wsparciu emocjonalnym kobiety i osób towarzyszących,

- $\quad$ kontrolowaniu parametrów życiowych rodzącej (tętno, ciśnienie i temperatura), nie rzadziej niż co 4 godziny,

- badaniu FHR płodu za pomocą elektronicznego detektora tętna płodu lub słuchawki Pinarda, nie rzadziej niż co 15 minut,

- $\quad$ kontroli postępu porodu za pomocą badania zewnętrznego (chwyty Leopolda, ocena czynności skurczowej macicy) oraz, jeśli jest to konieczne, badania wewnętrznego; dodatkowo bierze się pod uwagę zachowanie i odczucia rodzącej, 
- $\quad$ pilnowaniu nawodnienia i odżywienia rodzącej (dopuszczalne jest spożywanie lekkostrawnych posiłków oraz przyjmowanie płynów według potrzeb rodzącej),

- $\quad$ przypominaniu rodzącej o konieczności opróżnienia pęcherza moczowego, samodzielnie w toalecie,

- $\quad$ analizie bólu porodowego, w tym na stosowaniu niefarmakologicznych metod łagodzenia bólu oraz nauce prawidłowego oddychania rodzącej,

- umożliwianiu swobodnego poruszania się rodzącej z uwzględnieniem pozycji relaksacyjnych i immersji wodnej, prezentacji możliwych pozycji w II okresie porodu z uwzględnieniem potrzeb i stanu kobiety,

- dokumentowaniu postępu i przebiegu porodu, wyników obserwacji, wykonywanych badań oraz dobrostanu rodzącej i płodu, w tym prowadzeniu Karty Obserwacji Porodu,

- $\quad$ przygotowaniu zestawu do porodu oraz miejsca do odbycia II okresu porodu,

- w przypadku pozytywnego wyniku GBS u rodzącej - na podaniu w momencie rozpoczęcia porodu dawki antybiotyku i kontynuowaniu terapii do końca porodu $[8,11,18]$.

Drugi okres porodu rozpoznawany w chwili całkowitego rozwarcia szyjki macicy kończy się porodem noworodka. Do czynności wykonywanych na początku Il okresu porodu należy właściwe rozpoznanie tego etapu. Położna dokonuje tego poprzez badanie wewnętrzne, obserwacji zachowania rodzącej oraz czynności skurczowej. Jeśli nie wystąpiły żadne czynniki kwalifikujące do transferu, położna powinna:

- $\quad$ zapewnić optymalne warunki podczas narodzin dziecka,

- pozostawać w stałym kontakcie z rodzącą,

- $\quad$ wspierać rodzącą i osoby towarzyszące w momentach kryzysowych i oceniać ich stan emocjonalny,

- $\quad$ kontrolować parametry życiowe rodzącej (tętno, ciśnienie i temperatura); jeśli stan ogólny rodzącej przed rozpoczęciem II okresu porodu był prawidłowy, można odstąpić od wykonywania pomiarów w fazie aktywnej II okresu, z powodu niemiarodajnych wyników,

- $\quad$ badać FHR płodu za pomocą elektronicznego detektora tętna płodu lub słuchawki Pinarda, nie rzadziej niż co 5 minut, w fazie aktywnej po każdym skurczu,

- $\quad$ kontrolować postęp porodu za pomocą: badania zewnętrznego (chwyty Leopolda), oceny czynności skurczowej macicy, oceny zabarwienia płynu owodniowego oraz badania wewnętrznego (dodatkowo bierze się pod uwage zachowanie i odczucia rodzącej),
- uwzględnić fizjologiczną fazę spoczynku w II okresie porodu i przyjęć postawę wyczekującej,

- proponować rodzącej przyjęcie odpowiednich pozycji ułatwiających rodzenie na każdym etapie II okresu porodu; zalecić pozycje wertykalne i immersję wodną,

- $\quad$ pomóc przy wyborze i zastosowaniu techniki parcia, zalecać ograniczenie aktywnego odruchu parcia na rzecz naturalnego,

- dbać o regularne opróżnianie pęcherza moczowego,

- $\quad$ kontrolować stan nawodnienia rodzącej, podawać doustnie płyny w małych porcjach,

- $\quad$ przygotować się do przyjęcia porodu, zgodnie z zasadami aseptyki i antyseptyki,

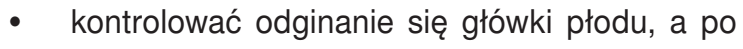
jej urodzeniu podjąć czynności zapewniające prawidłowe wytaczanie się barków,

- $\quad$ podjąć decyzję o porodzie z ochroną krocza lub o jego nacięciu,

- $\quad$ w razie konieczności wykonać zabiegi medyczne, takie jak amniotomia lub episiotomia,

- położyć noworodka bezpośrednio na brzuchu matki oraz osuszyć i zabezpieczyć go przed utratą ciepła,

- udokumentować działania, przebieg porodu oraz stan kobiety i noworodka - wypełnić dokumentację medyczną [8, 11, 18].

Okres łożyskowy obejmuje oddzielenie i wydalenie łożyska. Zadaniami położnej w tym okresie porodu są:

- zapewnienie kontaktu „skóra do skóry” zaraz po porodzie,

- ocena stanu noworodka zgodnie ze skalą V. Apgar,

- kontrola stanu ogólnego rodzącej (ciśnienie, tętno, temperatura), zachowanie kontaktu wzrokowego i słownego z kobietą,

- umożliwienie kobiecie i pomoc jej w przystawieniu dziecka do piersi jak najszybciej po porodzie (gdy matka i dziecko są na to gotowi),

- $\quad$ późne odpępnienie noworodka jałowymi narzędziami i zaopatrzenie kikuta pępowinowego,

- obserwacja w kierunku krwawienia z dróg rodnych i objawów odklejenia łożyska (nie należy pociągać za pępowinę, masować macicy, podawać rutynowo oksytocyny),

- ocena stanu tkanek miękkich kanału rodnego, a w przypadku nacięcia krocza - jego rozległości $[8,11,18]$,

- postępowanie z dzieckiem w sposób delikatny, co ma pozytywne skutki dla psychiki noworodka oraz jego formy fizycznej oraz umożliwia łagodniejsze przejście przez niełatwe przeżycia związane z porodem, 
- $\quad$ udokumentowanie swoich działań i obserwacji III okresu porodu - wypełnienie dokumentacji medycznej [34, 35].

Czwarty okres porodu obejmuje dwie godziny od momentu wydalenia popłodu. W tym czasie prowadzony jest intensywny nadzór nad położnicą. Do zadań położnej, przyjmującej poród w warunkach domowych, należy:

- ocena popłodu (pępowiny, błon płodowych oraz płyty łożyskowej),

- $\quad$ kontrola dróg rodnych: ocena pochwy, krocza, warg sromowych (nie ma konieczności rutynowej oceny szyjki macicy, jest to zależne od przebiegu porodu),

- $\quad$ zaopatrzenie chirurgiczne ewentualnych uszkodzeń dróg rodnych, nacięcia krocza,

- ocena utraty krwi przez położnicę,

- kontrola parametrów stanu ogólnego (tętno, ciśnienie, temperatura) godzinę i dwie godziny po porodzie,

- kontrola stanu noworodka,

- ochrona matki i dziecka przed utratą ciepła,

- w przypadku pozytywnego wyniku GBS u matki - pobranie krewi pępowinowej w celu oznaczenia CRP oraz wymazu z ucha noworodka [11, 18],

- wykonanie pomiarów antropometrycznych noworodka (masa ciała, obwód głowy, obwód klatki piersiowej, obwód brzucha, długość ciała),

- wykonanie zabiegu Credégo,

- zastosowanie profilaktyki krwawienia z niedoboru witaminy $\mathrm{K}[11,36]$,

- udokumentowanie swoich działań oraz obserwacji położnicy i noworodka - wypełnienie dokumentacji medycznej [11, 18].

Przed opuszczeniem miejsca porodu położna powinna:

- uzupełnić dokumentację medyczną przebiegu porodu (partogram, dokumenty noworodka, kartę obserwacji położnicy i noworodka, kartę informacyjną o porodzie) oraz udokumentować urodzenie dziecka (zaświadczenie o urodzeniu dziecka, karta uodpornienia, książeczka zdrowia);

- poinformować kobietę o konieczności samoobserwacji i kontroli stanu noworodka;

- $\quad$ poinformować położnicę o obowiązkowej wizycie pediatry w pierwszej dobie życia dziecka, poinformować o konieczności rejestracji dziecka w poradni preluksacyjnej i ustalenia terminu badania słuchu noworodka,

- poinformować o obowiązkowych szczepieniach ochronnych [18].

\section{Rola położnej w opiece nad położnicą po porodzie w warunkach domowych}

Opieka położnej nad kobietą i noworodkiem w okresie połogu polega na:

- kontroli parametrów stanu ogólnego (ciśnienie, tętno, temperatura),

- ocenie: obkurczania się mięśnia macicy, odchodów połogowych, gojenia się ran krocza,

- analizie stanu emocjonalnego położnicy,

- ocenie kondycji mięśni przepony moczowo-płciowej,

- ocenie: przebiegu laktacji, stanu brodawek, techniki przystawienia noworodka do piersi i karmienia,

- $\quad$ pobraniu krwi kobiety Rh ujemnej w kierunku przeciwciał i ewentualnie podaniu immunoglobuliny anty-Rh (w ciągu 72 godzin od porodu),

- poinformowaniu kobiety o konieczności samoobserwacji oraz instruktażu w zakresie kontroli obkurczania się mięśnia macicy,

- zaprezentowaniu ćwiczeń mięśni krocza i wyjaśnieniu powodu ich wykonywania od pierwszej doby po porodzie,

- $\quad$ nauce pielęgnacji noworodka (kąpiel, pielęgnacja kikuta pępowinowego),

- poinformowaniu o konieczności wykonania szczepień ochronnych zgodnie z obowiązującym kalendarzem szczepień,

- zdjęciu szwów z krocza lub rany pooperacyjnej około 5-7 doby połogu,

- poinformowaniu położnicy o zalecanej wizycie kontrolnej sześć tygodni po porodzie u lekarza ginekologa lub położnej,

- $\quad$ kontroli stanu ogólnego noworodka, która obejmuje: ilość i rodzaj oddechów, zabarwienie powłok skórnych, napięcie mięśniowe, charakterystyczne w okresie noworodkowym odruchy neurologiczne, wydalanie smółki i moczu, ocenę budowy czaszki, ciemiączka, stan obojczyków i stawów biodrowych,

- ocenie stanów przejściowych noworodka (np. masa ciała, stopień zażółcenia skóry),

- ocenie kikuta pępowinowego i pierścienia pępkowego,

- pobraniu krewi obwodowej w celu oznaczenia CRP i wykonaniu morfologii z rozmazem między 24. a 48. godziną życia - w przypadku pozytywnego wyniku GBS u matki lub gdy czas pęknięcia pęcherza płodowego przekracza 18 godzin,

- uzupełnieniu dokumentacji medycznej [18].

\section{Piśmiennictwo}

1. Rozporządzenie Ministra Zdrowia z dnia 4 października 2012 r. w sprawie standardów postępowania oraz proce- 
dur medycznych przy udzielaniu świadczeń zdrowotnych z zakresu opieki okołoporodowej sprawowanej nad kobietą w okresie fizjologicznej ciąży, fizjologicznego porodu, połogu oraz opieki nad noworodkiem. Dz.U.2012, poz. 1010.

2. Ustawa z dnia 15 lipca 2011 r. o zawodach pielęgniarki i położnej. Dz.U. 2011 nr 174 poz. 1039.

3. Informacje o wynikach kontroli Opieka okołoporodowa na oddziałach położniczych. NIK. Delegatura w Białymstoku, LBI.410.008.2015, Nr ewid. 203/2015/P/15/065/LBI.

4. Fundacja Rodzić po Ludzku http://www.rodzicpoludzku. pl/Porod-w-domu/Dla-kogo-porod-domowy-i-jak-sie-doniego-przygotowac.html, data wejścia: 10.01.2017.

5. Red: Janiuk E, Lichtenberg-Kokoszka E. Domowe narodziny. Fanaberia czy powrót do normalności? Oficyna Wydawnicza „Impuls”, Kraków 2010.

6. Gierszewska M, Kwiatkowska W, Kaźmierczak M, Mieczkowska E, Gebuza G. Poród domowy - anachronizm czy wybór i potrzeba świadomych kobiet? Perinatol. Neonatol. Ginekol. 2013; tom 6, zeszyt nr 4: 220-224.

7. Marczak I. W Kórniku czy w malinach. Narodziny na przełomie wieków. Wydawnictwo eMPi2 Mariana Pietraszewskiego s.c., Poznań 2015.

8. Cheyney M. Homebirth as Systems-Challenging Praxis: Knowledge, Power and Intimacy in the Birthplace. Qualitative Health Research 2008; 18; 254-267.

9. Autor rozdz. Kicia M. Poród naturalny. Iwanowicz-Palus G. [red.] Praktyka położnej: poród fizjologiczny.

10. Chołuj I. Urodzić razem i naturalnie. Fundacja Źródło Życia, Warszawa 2015.

11. Bernhard C, Zielinski R, Ackerson K, English J. Home Birth After Hospital Birth: Women's Choices and Reflections JMHW Volume 59, Issue 2, March/April 2014, Pages: 160-166.

12. http://www.rodzicpoludzku.pl/Porod-w-domu/Porod-wdomu-czy-to-legalne.html, wejście dnia: 07.12.2016.

13. GUS, Rocznik demograficzny, Warszawa 2015, str. 323.

14. Rolska P. Poród w domu. Położ. Nauka Prakt. 1 (17) /2012: 38-42.

15. http://www.dobrzeurodzeni.pl/statystyki.html, wejście dnia 07.12.2016.

16. European Perinatal Health Report Health and Care of Pregnant Women and Babies in Europe in 2010, str. 96.

17. Rekomendacje Polskiego Towarzystwa Ginekologicznego w zakresie opieki przedporodowej w ciąży o prawidłowym przebiegu. Polskie Towarzystwo Ginekologiczne.

18. Dzierżak-Postek E, Grzybowska K, Kruze M, Oleś K, Romanowska M, Witkiewicz M. Model kobiety nad kobietą i dzieckiem w fizjologicznym okresie okołoporodowym w praktyce pozaszpitalnej. Poł.Nauk.Prakt. 4 (12)/2010: 8-19.

19. Romanowska M. Przyjmuję porody domowe. Mag. Pielęg. Położ. 2011 (5): 32-33.

20. The American College of Obstetricians and Gynecologists. Committee Opinion No. 669: Planned Home Birth. August 2016.

21. National Institute for Health and Care Excellence (NICE) Intrapartum care for healthy women and babies during childbirth. CG190, December 2014.

22. Kitzinger S. Rodzić w domu. Medycyna dla wszystkich. Springer PWN, Warszawa 1995, s. 46.

23. de Jonge A, van der Goes B, Ravelli A, Amelink-Verburg M, Mol B, Nijhuis J, Bennebroek Gravenhorst J, Buitendijk S.
Perinatal mortality and morbidity in a nationwide cohort of 529688 low-risk planned home and hospital births. BJOG 2009; 116: 1177-1184.

24. American College of Nurse-Midwives. Midwifery Provision of Home Birth Services. J. Midwifery Womens Health 2016; 61: 127-133.

25. Blix E, Kumle M, Kjærgaard H, Øian P, Lindgren H. Transfer to hospital in planned home births: a systematic review. BMC Pregnancy and Childbirth 2014, 14: 179.

26. de Jonge A, Geerts CC, van der Goes BY, Mol BW, Buitendijk SE, Nijhuis JG. Perinatal mortality and morbidity up to 28 days after birth among 743070 low-risk planned home and hospital births: a cohort study based on three merged national perinatal databases. BJOG 2015; 122: 720-728.

27. Hutton E, Cappelletti A, Reitsma A, Simioni J, Horne J, McGregor C, Ahmed R. Outcomes associated with planned place of birth among women with low-risk pregnancies. CMAJ, March 15, 2016, 188(5).

28. http://www.rodzicpoludzku.pl/Pozaszpitalne-miejsca-do-porodu/Porod-domowy-relikt-czy-przyszlosc.html, data wejścia: 08.12.2016 rok

29. Snowden MJ, Tilden LE, Snyder J, Quigley B, Caughey BA, Cheng WY. Planned Out-of-Hospital Birth and Birth. The New England Journal of Medicine December 2015; 373; 27.

30. Zielinski R, Ackerson K, Kane Low L. Planned home birth: benefits, risks, and opportunities. International Journal of Women's Health 2015: 7, 361-377.

31. Dzierżak-Postek E, Grzybowska K, Romanowska M. Poród pozaszpitalny. Mag. Pielęg. Położ. 2009: 7-8.

32. Autor rozdz. Chazan B. Położnictwo i Ginekologia. Tom 1. Rozdz. Rozpoznanie ciąży i ustalenie terminu porodu. Red: Bręborowicz G. Wydawnictwo Lekarskie PZWL, Warszawa 2010, str. 53-57.

33. Richmonda S, Wyllie J. Resuscytacja noworodków bezpośrednio po urodzeniu. Wytyczne resuscytacji 2010.

34. Red: Lichtenberg-Kokoszka E, Janiuk E, Dzierżanowski J. Dziecko aktywny uczestnik porodu. Zagadnienie interdyscyplinarne. Oficyna Wydawnicza „Impuls”, Kraków 2010.

35. Leboyer F. Narodziny bez przemocy Wydawnictwo Mamania, Warszawa 2012.

36. Świetliński J. Neonatologia i opieka nad noworodkiem. Tom 1, Wydawnictwo Lekarskie PZWL, Warszawa 2015.

Artykuł przyjęty do redakcji: 19.10.2018.

Artykuł przyjęty do publikacji: 29.08.2019.

Źródło finansowania: Praca nie jest finansowana z żadnego źródła. Konflikt interesów: Autorzy deklarują brak konfliktu interesów.

Adres do korespondencji:
Katarzyna Plagens-Rotman
ul. Jackowskiego 41
60-512 Poznań
tel. 61 854-72-25
e-mail: plagens.rotman@gmail.com
Katedra Zdrowia Matki i Dziecka, Uniwersytet Medyczny im. Karola
Marcinkowskiego w Poznaniu

